\title{
Pak-Afghan Relations Post 9/11: Amarat Islami Afghanistan and Afghan Peace Agreement and its Problems
}

\author{
*Abdul Sadiq Khan \\ "Dr. Muhammad Usman Tobawal
}

\section{ABSTRACT:}

Pakistan is the most imperative neighbor for peaceful Afghanistan and the relationship between both countries is based on complex national understanding of regional threat perception. The analytical investigation of the Pak-Afghan engagement with respect to Afghan War represents that Pakistan impulsively calculated its strategic objectives under the influence of an urge to make an alliance against Indian hegemony in South Asia. Whereas, New Delhi's primary target in Kabul was to stop Islamabad in coagulating a mutual block of Taliban that would be important to Pakistan at the time of crisis with India. The risk of prospective military assistance from Taliban to Kashmiri separatists was determined strategically by India. Recently, Indian Consulates in Afghanistan has coherently operated under the influence of infamous Ajit Doval Doctrine, to build an insurgency in Pakistan that focuses primarily on Pakistan's inner disruption by cross-border fighting, civilian targeting and proxy war. New Delhi is lobbying in Washington to enhance its diplomatic influence in Afghanistan and also bilaterally engaging with Afghan government to create favorable circumstances through its intelligence networks. After the U.S. attack on Afghanistan, India has founded a great opportunity to minimize Pakistan's strategically role in Afghanistan. The Taliban may eventually agree to dichotomy of power, but they are uncertain about their rigidly undemocratic leadership attitude. A two-level mode of governance is therefore likely to be included in the potential future political system of Afghanistan.

Keywords: Afghanistan, Pakistan, Peace Process, Taliban, South Asia.

\section{Introduction}

The 9/11 attacks and US's subsequent launching of "Operation Enduring Freedom" provided India an opportunity to bend its foreign policy toward attaining a hegemonic position in the region. Since 2001, India has drastically enhanced its consular and intelligence presence and increased its political and economic clout in Afghanistan ${ }^{1}$. India has offered \$1.2 billion for Afghanistan's reconstruction, making it the largest regional donor to the country ${ }^{2}$. It also has several completed and ongoing development projects in Afghanistan including the completed construction of the Zaranj-Delaram highway in southwest Afghanistan near the Iranian border; the building of Afghanistan's new parliament building and the construction the Salma Dam power project in Herat Province $^{3}$. In October 2011, India fortified its ties with Afghanistan by signing the

*PhD Scholar, Pakistan Study Center, University of Balochistan Quetta.

Email: sadiqk2009@gmail.com

"Director, Pakistan Study Center, University of Balochistan Quetta. 
Strategic Partnership Agreement (SPA) ${ }^{4}$. This agreement between the two sides would encourage investment in Afghanistan's natural resources and provide duty free access to the Indian market for Afghanistan's export products. From the Afghan side, there had been high level visits to India, including President Hamid Karzai's state visit in Nov 2012, which included intensive discussions with political and business leaders, and oversaw the signing of four Memoranda of Undertakings (MoUs) with India 5 .

On the other hand, relations between Pakistan and Afghanistan have traditionally been overwrought and embedded in perpetual mistrust with the exception of a few brief moments of stability. After the ouster of the Taliban regime and subsequent govt: of Hamid Karzai, Pak-Afghan ties followed a downward trajectory as the gaps in mistrust and continuous blame game grew between Islamabad and Kabul ${ }^{6}$. Hence, when the govt: of national unity took over in 2014, relations between Kabul and Islamabad witnessed a visible improvement in ties which were not limited to the political arena. However, this visible improvement in ties temporary, as relations once again fell victim to the blame game primarily because of the failure of the peace process with the Afghan Taliban, counter-terrorism differences and the issue of Afghan refugees ${ }^{7}$. Given its geographical proximity to Afghanistan, cultural and ethnic ties, and its involvement in the Afghan 'jihad' against the Soviets and more recently the 'war against terrorism,' Pakistan is Afghanistan's most important regional player that has always been affected by events in Afghanistan. Although Afghanistan's challenges have been domestic in nature, such as insecurity and violence, Afghan Taliban insurgency, the growing ethnic divide, a weak economy, rampant illicit drug trade, interflow of refugees and unmonitored cross-border movement of ordinary civilians and militants; these home-grown issues have a direct impact on Pakistan, as has been witnessed over the past decade or so $^{8}$. Particularly after the events of $9 / 11$, not only have Pak-Afghan ties drastically deteriorated to what may be the worst of Pak-Afghan crisis witnessed in the past few decades, the ongoing instability in Afghanistan has had a particularly negative effect on Pakistan's security, economy and society. Although Robert D. Kaplan of the Atlantic Monthly wrote that "Afghanistan has been a prize that Pakistan and India have fought over directly and indirectly for decades," Pakistan has suffered the most due to instability and violence in Afghanistan. In addition to accommodating and welcoming more than 1.64 million Afghan refugees, Pakistan has continuously supported Afghanistan in fighting against its internal instability and terrorism. However, the resurgence of the Taliban movement and the growing insurgency in the provinces bordering the Pakistan-Afghan border has generated tensions between Kabul and Islamabad ${ }^{10}$.

In the post-9/11 era, the Afghan claim on Pakistan's Pashtun territories persists, and Kabul still refuses to recognize the Durand Line as the international border between the two countries. Pakistan, despite rejecting the allegations, has been accused not only by India, but also by Afghanistan, of backing and funding Taliban against the Afghan government. According to the Afghans, 'Pakistan fears a stable Afghanistan because it would revitalize the Pashtun issue and establish a reverse alliance with 
India $^{11}$. Strategic rivalries over and in Afghanistan are one of the main obstacles to peace in Afghanistan and the region ${ }^{12}$. In the recent past, this policy objective has been the main source of concern due to apprehensions regarding India's support and abetment to terrorist and nationalist elements in Federally Administered Tribal Areas (FATA) and Baluchistan. Pakistan's bilateral relations with Afghanistan are significantly dependent on India's influence in Afghanistan. Although successive Afghan leaders, have made assured that Afghanistan would not indulge in the Indo-Pak rivalry and not allow its territory to be used against Pakistan, ground realties indicate the opposite ${ }^{13}$. India has made several attempts to diplomatically, politically and economically isolate Pakistan in the international community by establishing its soft power in Afghanistan, pulling out of 19th South Asian Association for Regional Cooperation (SAARC) summit, accusing Pakistan of supporting and financing terrorism during the Heart of Asia conference and excluding Pakistan from its various trade agreements and projects with Iran and Afghanistan. Although Pakistan and Afghanistan have a common war fighting against a common enemy and Pakistan committed to provide \$250 million for reconstruction in Afghanistan after 2001, India's growing influence and presence in Afghanistan has severed Pak-Afghan ties since India's foreign policy in Afghanistan is aimed at isolating Pakistan and strengthening its foothold in Afghanistan in order to establish political, strategic, social and economic dominance over Pakistan through Afghan territories. Hence, in the midst of cross-border clashes due to infiltration of terrorists from Afghanistan across the porous Durand Line, accusations of supporting terrorism and India's growing influence in Afghanistan, Pak-Afghan relations have been detrimental in the post-9/11 era.

\section{Theoretical Framework}

The study on post-9/11 Afghanistan and its implications on India and Pakistan will be analyzed from the realist perspective. Various aspects of the research question will be considered from different variants of realism, including classical realism, neo-realism and neo-classical realism. Considering the realist perspective, this paper will show how Afghanistan, India and Pakistan, as states and governments, have played the roles of central actors in the international politics. Despite the 'role' of entities like UN and the NATO in the issue of "War on Terror," it is the individual states of Afghanistan, US, India and Pakistan who decide the course of actions in order to maximize their power and self-interests, domestically, regionally and globally. Additionally, this study will also look at the issue through the lens of Regional Security Complex Theory (RSCT) that focuses on how security is clustered in geographically shaped regions and how the security of states in a region interacts with the security of the other actors. The magnitude of relations between Pakistan and Afghanistan fall within the Realist paradigm since the very machinations of the theory of Balance of Power $(\mathrm{BoP})$ are at work in the complex pattern of relations between the two countries. The regional players are hard core realists in the real Kautilya fashion because they are busy courting the neighbors of their immediate neighbors, promoting state power and its supremacy and applying the realist motto- 'The ends justify the means' in domestic and international politics. 
Barry Buzan's framework for security analysis at domestic, regional and global levels provides the theoretical basis for the study. The study underscores that PakistanAfghanistan relations in the post 9/11 era eroded South Asia's security at all the three levels i.e. domestic, regional, and global. At the domestic level, Pakistan's debilitating polity marred by the ever-increasing extremism and spiraling violence have unleashed dangerous centrifugal forces. At the regional level, the hostile policies of the Afghan government along with hawkish statements by the Afghan elite coupled with the looming danger of the Durand Line being exploited by the Afghan Government poses only one set of problems for Pakistan. Additionally, India's success at the expense of beleaguered Pakistan in reviving its old links with the people and government of Afghanistan is more disturbing for Pakistan, for it finds itself trapped between the devil and the deep sea. At the international level, the presence of International forces, chiefly the US so close to Pakistani border with demands to carry out operations along with the Afghan National Security Forces (ANSF) in order to flush out the Taliban and Haqqani network coupled with the occasional violation of its territorial integrity by these forces, have serious ramifications for Pakistan's domestic cohesion and its overall partnership with the international coalition to combat terrorism.

\section{Pak-Afghan Relations}

Pakistan is a most imperative neighbor for peaceful Afghanistan, and on an enormous magnitude, both countries' relations are reliant on the nature of threat perception with each other. During the colonial era, the extension of India commenced towards Afghanistan, and it quickly seized territories related to Punjab state held by Ranjit Singh under British rule ${ }^{14}$. The expansion of Russia as a great power in Central Asia encouraged Great Britain to politically and militarily interpose in Afghanistan. Subsequently, the 'ancient empire' of Afghanistan altered into a buffer state by demarcating its borders along with the Russians and Great Britain under the Durand Line agreement of 1893, which established a state of Afghanistan. Eventually, being a successor state in 1947, Pakistan has acceded to this inheritance of the colonial rule in its Western region. The critical analysis of the period, 1947 to 1978, the concerns magnified regarding border issues and Pushtunistan, persisted as a foremost apprehension for Pakistan's international diplomacy and ruined the associations among Kabul and Islamabad in concerned decades. This level of aggressive dealings amongst Pakistan and Afghanistan provided an opportunity to the Union of Soviet Socialist Republics for a swift expansion to exert influence on Afghanistan ${ }^{15}$. India's underground affairs with Afghanistan performed a spoiler role for the emerging relations of Pakistan and Afghanistan. Supplementary, the Indo-USSR strategic association in the Cold war added another dimension of threat perception for Pakistan concerning Afghanistan. Subsequently, Pakistan thrived for the implementation of a well-organized defensive policy regarding Afghanistan. The primary aim of this defensive policy was to guarantee the advent of a approachable govt: in Afghanistan, which will ensure peace and stability along the Western borders. In the 1950s, Pakistan was failed to comprise an inclusive Afghan policy, and it only relied upon the short-term reactionary policy vis-à-vis to Afghanistan's engagements ${ }^{16}$. 
Pakistan inherited the territorial disagreements after the completion of colonial rule in the Sub-Continent, and these disputes were the main source of complex engagement in the matter of formulating its foreign policy. The two highly-anticipated territorial disputes were the Kashmir and Durand line along its Eastern and Western borders, respectively. The foremost commotion between Kabul and Islamabad was on the settlement of North-Western territories. This settlement was not appropriately negotiated from both sides and instigated the foreign policy concerns about Durand Line. After the independence of Pakistan, inharmoniousness between Kabul and Islamabad has endured a virtually constant factor in Pakistan's policy regarding Afghanistan. There is no uncertainty that Afghanistan symbolizes one of the furthermost urgent and decisive issues for Pakistan in terms of its safety, internal politics, security, and socio-economic progress ${ }^{17}$.

Nonetheless, the apparent risks related to the security compelled defense arrangements were the principal significance for the initial Pakistani administrations, since the initiation of the subsequent government of the country in 1947. The military institution was seen as the first line of defense, and its role was emerged as the sole organization accountable for the security and defining the conflict resolution mechanism for Pakistan $^{18}$. It was natural that a security-driven state of Pakistan started to distinguish India as its supreme opponent, and the Eastern neighbor was portrayed as a destructive power to endangered the newly born Islamic state. The contentious issues with Afghanistan added another dimension of threat perception in Pakistan's security policy. Consequently, the earlier administrations forced to liquidate approximately 75 percent of resource allocation for defense purposes in the early $1950 \mathrm{~s}^{19}$.

\section{Saur Revolution: Tip of The Iceberg}

In the timeline of history related to Afghanistan, the Saur Revolution of April 1978 became a triggering point for continuous political instability in the region. Notwithstanding, the Saur Revolution was a milestone to put an end to monarchy and a proper democratic process was initiated in Afghanistan after the victory of PDPA ${ }^{20}$. After the Soviet invasion of Afghanistan, the president of United States, Jimmy Carter, termed this incursion as a grave threat to international peace since the World War 2 and urged his nation to pump in resources for the assistance of Pakistan to expedite American designs $^{21}$. The US support to anti-communist groups in Kabul was also quantified as a provocation for the USSR intervention in Afghanistan. This United States' aid to antiSoviet forces can be seen months aforementioned to the USSR incursion in Afghanistan. Initially it was estimated that all the required functions of managing Mujahedeen from weapon training programs to orchestrate tactical operations against Soviets - would cost 60 million dollars but in 1984 the expenditures went as high as 400 million dollars. Gulbaddin Hikmatyar of Hezba-Islami was the major recipient of aid provided by the United States. There is no doubt that Pakistan outsmart the USSR by efficient manipulation of resource constraints and Islamabad was successful in providing the required training to Afghan Mujahedeen ${ }^{22}$.

\section{Emergence of Taliban}


The emergence of Taliban can be quantified as a productivity of disintegrated Afghanistan. This new force started to assemble momentum and developed into a commanding power that make the security situation in Afghanistan more complex. The mainstream of the Taliban's was among the persons who were skilled and educated in Pakistan's refugee camps. Therefore, Taliban were more sympathetic and aligned with Pakistan's policies as compared to other countries. The quarters which were considering Taliban as small group of unorganized militants confounded after Taliban's successful attack on Tobba Achakzai arms and ammo store in October 1994. Strategic analysts were astonished by this tactical surprise and quickness of operation allowed Taliban to assist them with owning more than 80,000 Kalashnikovs and several thousands of ammo rounds ${ }^{23}$.

After dealing with this resistance Taliban effortlessly overwhelmed the historic city place of Kandahar on fifth November 1994. The victory over Kandahar by Taliban brought up the rebellions in government powers and after that many factions joined Taliban. Taliban successfully merged their power in strategically important Kandahar city and displayed urge to capture Kabul in North and Herat in West. The pace, Taliban picked up was converted into a momentum which ultimately resulted into their dominance in nine provinces of Afghanistan. Charasyab surrendered to Taliban in February, Herat was captured by them in September, Jalal Abad and Kabul was overrun by Taliban in September 1996. Conspicuously, India gave part of monetary, material and conciliatory help to Rabbani and Ahmad Shah Masood for facilitating the upgradation of their capability and ability to withstand Taliban threat ${ }^{24}$.

It was widely reported in Pakistan that India has provided monetarist and military funding to Rabbani's regime and in June 1995 Indian cargo planes directly delivered aid to Rabbani forces at Bagram airbase. It was also reported that Indian trained pilots were tactically using Afghan planes for the benefit of Rabbani forces. In May 1997, Taliban were administrating 27 provinces out of 32 and they were in control to almost all of Afghanistan. While following the Chanakya ideology of "your enemy's enemy is your friend," India went hard and fast to help Rabbani and Ahmad Shah Masood who were the staunch opponent of Pakistan's maintenance to Taliban. India through active diplomacy flourished the misconception among Pakistan and Iran by tossing the narrative that Islamabad on the directives of Washington is associating Taliban with the objective of threatening Tehran. Therefore, India and Iran started to anticipate Taliban as common enemy.

However, New Delhi's foremost target in Kabul was to stop Islamabad in coagulating a mutual block of Taliban that would be important to Pakistan at the time of crisis with India. India was strategically calculating a threat perception of future support to Kashmiri insurgents from Taliban. Therefore, Rabbani and Masood were the last hope for India to counter the expansion of Taliban in Afghanistan.

Pakistan to strengthen its relations with Taliban regime stepped forward to politically recognize them on May 1997 as legitimate power in Afghanistan. This recognition was endorsed when Taliban successfully take over Mazar-e-Sharif. Pakistan established its 
case of recognition on the argument that Taliban government was meeting all the desired prerequisites according to International Law. Now Taliban government was in viable control of the vast majority of Afghanistan and the regime included delegates of all the ethnic factions. After the recognition of Pakistan, prominent Middle Eastern countries like Saudi Arabia and United Arab Emirates (UAE), were next in line to politically support Taliban government ${ }^{25}$.

\section{Afghan Peace Agreement and its Problems}

The reports, last year, that United States had decided to extract soldiers from Syria since December 2018 made it evident that the declaration about with drawing of soldiers from Afghanistan would be result of it. The revived effort by the Trump administration to reconcile with the Taliban had highlighted this eventuality since late 2018. On $20^{\text {th }}$ Dec 2018, the narrative arose about U.S. departure from Afghanistan, quoting unidentified American defense officers. This media alert puts Afghanistan's neighbors in a security-related critical position and they were cautious about negotiating with Taliban to protect their potential gains in the regional context ${ }^{26}$. This development revealed that the strategies had been changed to remain relevant with the evolving security dynamics of Afghanistan.

Pakistan's strategic objectives concerning the future of Afghanistan have associated with its anxieties for the existence of New Delhi's diplomatic forces in Kabul, which Islamabad thinks presents immediate safety and security risks. New Delhi's enhancing efforts regarding Kabul's emerging posture will remain to play an important role in Pakistan's view regarding Afghanistan. Islamabad has also troubled with the transportation paths, ore mineral mining, harbor growth, and it is also apprehensive about direct relations with KSA, Iran, China, and Russia ${ }^{27}$. Moreover, no nation is in position to select the victors and losers regarding the outcome of the Afghan crisis. All nations, working for all parties with each other and with Afghanistan itself, have defined present and potential geopolitical rivalry in Kabul. The developing situation has also depicted that, if not outright disapproval, there is also some significant uncertainty within the Taliban factions. They were unable to decide whether they would encounter strategically with Pakistan while in Islamabad for discussions with the U.S. officials. A Foreign Policy journal paper asserted that distinctions existed between Taliban factions who should have belonged to the committee to encounter Imran Khan, Prime Minister of Pakistan. Taliban factions didn't reach an agreement on the formal timetable for their conference with Imran Khan because they wished to prevent the feeling that they follow the notation of Pakistan ${ }^{28}$.

\section{Conclusion}

The critical assessment from 1947 to 1978, the worries about the borders \& Pushtunistan continued as a main concern for Pakistan's global relations and destroyed Kabul / Islamabad partnerships during the centuries in respective decades. For friendly Afghanistan, Pakistan is a most essential neighbor and the relation between both nations relies on the complexity of perception of the threats at regional level. The regional disputes (especially with Afghanistan) of Pakistan were the primary cause of 
complicated involvement in the development of its foreign policy after the fall of colonial rule in the subcontinents. While Pakistan and Afghanistan had the coherence of faith and cultural variety, in their turbulent history both nations have continued along the road of dispute.

In early 1980s India through diplomatic soft power, tries to manipulate jittery relations between Kabul and Islamabad to outflank Pakistan's security position on its Western border. The critical examination of the Pak-Afghan relation with respect to Afghan War represents that Pakistan prematurely measured its strategic objectives under the influence of an urge to make an alliance against Indian hegemony in South Asia. During this period in order to attain a particular position in the US strategical calculus, Pakistan intervened dramatically in Afghan politics. The strategies of Zia's govt: namely, to associate the Mujahedeen fight in Afghanistan with the assistance of the US and the Western States have had a ruinous effect on the inhabitants of both nations. The Zia's policy to deal with Afghan War negatively impacted the social fabrics; society was indoctrinated by radicle curriculum; opened a rancorous religious fissure and started a fresh wave of terrorist attacks in Pakistan.

The Afghan authorities have been skeptical of Pakistan since the terror attacks of 11 September 2001. Distrust and absence of trust-building policies between the authorities are the cause of the declining political scenario between Pakistan and Afghanistan. The US incursion and installment of puppet regime in Afghanistan completely changed the geo-political environment of the region and simultaneously increased the security challenges for Pakistan. In the situation after September 11, Pakistan anticipated the Afghan administration's tilting tendency toward India. In the course of Ajit Doval Doctrine, Indian Consulates in Afghanistan are collaborating on the establishment of an insurgency in Pakistan, whose main goal has been internal destabilization of Pakistan through cross-border warfare, bombing and proxy conflict. On the other hand, New Delhi is lobbying in Washington for its role in Afghanistan and also bilaterally engaging with Afghan government to create favorable circumstances through its intelligence. India has discovered an enormous chance to minimize Pakistan's impact in Afghanistan after the US attack in early 2000s.

Although the government under the command of President Ashraf Ghani has enormous aspirations, the difficulties regarding peaceful resolution of Afghan crisis are also great. The newly elected regime of President Azhraf Ghani and the next coming elections in Afghanistan are not only fundamental for strategic stability of the region but also crucial for the peace initiative created regarding Afghanistan by international community. It took almost one and half decades of terrorism, insecurity and violence for elites in Kabul and the great powers to understand that harmony cannot be accomplished in Afghanistan without building structural changes for peaceful initiatives with the insurgents through productive arrangements and negotiations. Therefore, Ghani's regime has taken a severe effort to bring about harmony with insurgent groups and to resolve the military crisis in Afghanistan, knowing about the errors of the past Government. Uncertainty regarding the ultimate 
form of the discussions (that nothing is decided until all is decided) is stalks from: the spirited reluctance of Taliban to adhere to an overall ceasefire, their resistance to the Afghan regime's involvement in peace talks, America's refused to hurriedly remove soldiers and ease their legal sanctions against Taliban rulers, and inarticulacy on the Taliban's insurances that 'terror' offenses, like ISIS, do not use Afghan land against the US interests. For a long time, the Afghan conflict has been stalemated. Even with the US assistance, the State of Afghanistan has unable to reverse the conflict. On the other hand, the Taliban have extended their scope to the vicinity, but not in the urban cities. The best way forward in this situation is through process of peace talks, but the issue is whether America offers the Afghan regime too much space to escape its longest armed conflict. In contrast, a great compromise was the choice to maintain India in the peace process. The removal of the United States' troops from Afghanistan will be worse than Vietnam ignominy and will put profound marks in the psyche of the US, its constructed military alliance and Afghans at domestic level. All of the US human investment and taxpayer's trillions of dollars are lost for nothing. This is a flagrant violation of the confidence placed by the Afghans in America.

The Taliban could eventually consent to distribute authority, but their rigidly antidemocratic governance stance is doubtful to be amended. Therefore, a two-level governance style in Afghanistan is probable to be included in the future political system. This would comprise of political system of appointed and non-elected governance comparable to nations like Lebanon, Egypt, and Iran that could potentially be a state with clerical supervision. The most precious chance that the US should be able to reap is the latest peace negotiations. The US should reject its posture of permitting the state of Kabul, planted by the US, in the form of 'Legitimate Afghan Government' to take part in the Inter-Afghan Peace Conference. A reasonable figure of leaders from Kabul regime, who could be considered serious about the ongoing discussion, may be certified to participate in intra-Afghan dialogue. The US officials should promote these conference sessions so that Afghans can decide independently what kind of next administration they want, and when US / NATO army would exit from Kabul. Significantly, the residual impact of Pakistan on Afghanistan Taliban can provide the necessary assistance in such attempts.

\section{References.}

${ }^{1}$ Khan,A.(2014) Pakistan-Afghanistan Relations: Post 2014 Challenges. Strategic Studies Quarterly, 34 ${ }^{2}$ Bajoria, J. (2009, July 22). India-Afghanistan Relations. Council on Foreign Relations (blog). Retrieved from https://www.cfr.org/backgrounder/india-afghanistan-relations.

${ }^{3}$ Ibid.

${ }^{4}$ MIA.(2011, Oct 4). Text of Agreement on Strategic Partnership between the Republic of India and the Islamic Republic of Afghanistan. Ministry of External Affairs, Government of India. Retrieved from https://mea.gov.in/bilateraldocuments.htm?dtl/5383/Text+of+Agreement+on+Strategic+Partnership+be tween+the+Republic+of+India+and+the+Islamic+Republic+of+Afghanistan.

${ }^{5}$ Kalis, N. A. \& Lone, R. M. (2013). Indo-Afghan Relations after September 11: Implications for Pakistan. IOSR Journal of Humanities and Social Science, 15 (3), 10. 
${ }^{6}$ Khan,A.(2014) Pakistan-Afghanistan Relations: Post 2014 Challenges. Strategic Studies Quarterly, 34 ${ }^{7}$ Ibid.

${ }^{8}$ Bajoria, J. (2009, July 22). India-Afghanistan Relations. Council on Foreign Relations (blog). Retrieved from https://www.cfr.org/backgrounder/india-afghanistan-relations.

${ }^{9}$ Westerby, R. \& Ngo-Diep, S. (2013). Welcome to Europe! A Comprehensive Guide to Resettlement. Belgium: édition \& imprimerie.

${ }^{10}$ Grare, F. (2006). Pakistan-Afghanistan Relations in the Post-9/11 Era. Carnegie Endowment for International Peace. $\quad$ Retrieved August 20, 2020, from https://carnegieendowment.org/files/cp72_grare_final.pdf

${ }^{11}$ Khan,A.(2014) Pakistan-Afghanistan Relations: Post 2014 Challenges. Strategic Studies Quarterly, 34 ${ }^{12}$ Ibid

${ }^{13}$ Bajoria, J. (2009, July 22). India-Afghanistan Relations. Council on Foreign Relations (blog). Retrieved from https://www.cfr.org/backgrounder/india-afghanistan-relations.

${ }^{14}$ Omrani, B. (2009). The Durand line: History and problems of the Afghan-Pakistan border. Asian Affairs, 40 (2), 177-195.

${ }^{15}$ Siddiqui, A. J. \& Butt, K. M. (2014). Afghanistan-Soviet Relations during the Cold War: A Threat for South Asian Peace. South Asian Studies, 29, 617-631.

${ }^{16}$ Wagner, C. (2010). Pakistan's Foreign Policy between India and Afghanistan. Security and Peace, 28 (3), 246-251.

${ }^{17}$ Shah, M. A. (1997). The Foreign Policy of Pakistan: Ethnic Impacts on Diplomacy, 1971-94. IB Tauris.

${ }^{18}$ Hussain, R. (2005). Pakistan and the emergence of Islamic militancy in Afghanistan. Aldershot: Ashgate.

${ }^{19}$ Noman, O. (1990). Pakistan: A political and economic history since 1947. Routledge.

${ }^{20}$ Matinuddin, K. (1991). Power Struggle in the Hindu Kush: Afghanistan, 1978-1991. Lahore: Wajidalis

${ }^{21}$ Carter, J. (2008). The State of the Union Address Delivered Before a Joint Session of the Congress. Retrieved August 20, 2020, from https://www.presidency.ucsb.edu/documents/the-state-the-unionaddress-delivered-before-joint-session-the-congress

${ }^{22}$ Marvin G. Weinbaum. (1996). Pakistan And Afghanistan: Resistance And Reconstruction. New York: Avalon Publishing.

${ }^{23}$ Matinuddin, K. (1991). Power Struggle in the Hindu Kush: Afghanistan, 1978-1991. Lahore: Wajidalis

${ }^{24}$ Ibid.

${ }^{25}$ Ibid.

${ }^{26}$ Mashal, M. (2018, December 20). The US to withdraw about 7,000 troops from Afghanistan, officials say. New York Times. Retrieved from https://www.nytimes.com/2018/12/20/us/politics/afghanistantroop-withdrawal.html.

${ }^{27}$ Wagner, C. (2010). Pakistan's Foreign Policy between India and Afghanistan. Security and Peace, 28 (3), 246-251.

${ }^{28}$ Shakil, F. M. (2018, February 2). Chabahar Port lures Afghan traffic away from Karachi. Asia Times. Retrieved from https://asiatimes.com/2018/02/afghan-port-shift-adds-pakistans-economic-woes/.

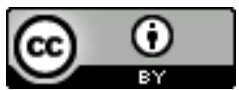

This work is licensed under a Creative Commons Attribution 4.0 International License. 